\title{
OECD Ülkelerinde Vergi Takozu ve İşsizlik İlişkisi
}

Araştırma Makalesi /Research Article

\section{Güray AKALIN ${ }^{1}$}

ÖZ: Vergi takozunun erkek ve kadın işsizlik oranları üzerindeki ampirik etkisinin ortaya konulması, işsizliği azaltmaya yönelik oluşturulacak politikaların etkinliğini arttırabileceği gibi bu politikalarda çeşitliliğe gidilebilmesine de katkı sağlayacaktır. Buradan hareketle, bu çalışmada 36 OECD ülkesinde vergi takozunun toplam, kadın ve erkek işsizlik oranları üzerindeki etkisi, 2000-2019 dönemi için Sistem GMM yöntemi ile araştırılmıştır. Çalışmada bağımsız değişken olarak vergi takozunun yanı sıra iktisadi büyüme, enflasyon ve ticari açıklık da kullanılmıştır. Sistem GMM yöntemi ile elde edilen bulgular şöyle siralanabilir: i) Vergi takozundaki bir artış toplam, erkek ve kadın işsizlik oranlarını artırmaktadır. ii) Ekonomik büyüme, enflasyon ve ticari açılklktaki bir artıs, toplam, erkek ve kadın işsizlik oranlarını azaltmaktadır. iii) Vergi takozunun işsizliği arttırıcı etkisi kadınlara kıyasla erkeklerde daha fazladır.

Anahtar Kelimeler: Vergi Takozu, İssizlik, OECD, Sistem GMM

Jel Kodu: C33, E2, E24, H2

\section{Tax Wedge and Unemployment Nexus in OECD Countries}

\begin{abstract}
Exhibiting the tax wedge's empirical effect on male and female unemployment rates may increase policies' effectiveness to reduce unemployment and contribute to diversification in these policies. From this point of view, in this study, the tax wedge's effect on total, female and male unemployment rates in 36 OECD countries was investigated for 2000-2019 by the System GMM method. Besides the tax wedge, economic growth, inflation, and trade openness were also used as independent variables in the study. The findings obtained with the System GMM method can be listed as follows: i) An increase in the tax wedge increases the total, male, and female unemployment rates. ii) An increase in economic growth, inflation, and trade openness reduce the total, male, and female unemployment rates. iii) Unemployment increasing effect of the tax wedge is higher for males compared to females.
\end{abstract}

Keywords: Tax Wedge, Unemployment, OECD, System GMM

JEL Codes: C33, E2, E24, H2

Geliş Tarihi / Received: 23/10/2020

Kabul Tarihi / Accepted: 16/02/2021

\footnotetext{
${ }^{1}$ Dr. Öğr. Üyesi, Kütahya Dumlupınar Üniversitesi, İktisadi ve İdari Bilimler Fakültesi, İktisat Bölümü, Kütahya / Türkiye, guray.akalin@dpu.edu.tr, orcid.org/0000-0002-6647-5418.
} 


\section{Giriș}

İşsizlik önemli ölçüde iktisadi ve sosyal maliyetleri olan, bu nedenle de hem politika yapıcılar hem de ekonomistler tarafından sürekli ilgilenilen temel iktisadi problemlerden bir tanesidir. Ekonomi teorisi ve ampirik çalışmalar, işsizliğin iktisadi dalgalanma, işsizlik ödenekleri, sendikalaşma oranı ve pazarlık gücü, ticaret, istihdam koruma mevzuatı ve rekabete aykırı ürün piyasası düzenlemesi gibi birçok kurumsal ve iktisadi faktörden etkilendiğini ortaya koymuştur (Bassanini ve Duval 2006: 3). Bu faktörlerden birisi de son y1llarda çok sayida tartışmaya konu olan vergi takozudur (Góra vd. 2006:6; OECD, 2006: 60; Dolenc ve Laporšek, 2010:344) ).

Çalışanın ödediği gelir vergisi ve sosyal sigorta primleri ile işverenin bordro üzerinden ödediği sigorta primi ve vergilerin toplamının, toplam işgücü maliyetine oranı şeklinde hesaplanan vergi takozundaki değişimler istihdamı farkl1 kanalardan etkileyebilmektedir (Hodge ve Hickman, 2018: 2; OECD, 2020a). Bu kapsamda, daha yüksek vergi takozu birim başına daha fazla işgücü maliyetine yol açtığından işgücü talebini azaltmakta ve işsizliği arttırmaktadır (Ederveen ve Thissen, 2004: 18; Šeparović, 2009: 449; Dolenc ve Laporšek, 2010: 384; Attinasi vd. 2016: 6; Todorović vd. 2018: 62). Daveri ve Tabellini (2000)'e göre işgücü piyasası rekabetçi değil ise işgücü maliyetlerindeki dişsal ve kalıcı bir artış, işgücü talebinde azalmanın yanı sıra firmaların artan işgücü maliyetleri nedeniyle üretimde emek yerine sermaye ikame etmelerine yol açmaktadır. Üretimde emek yerine sermayenin ikame edilmesi ise sermayenin marjinal verimliliğinin düşmesine neden olmakta ve uzun dönemde büyüme için gerekli yatırımlar azalmaktadır. Böylece yüksek işsizlik yavaş büyüme ve düşük yatırım ile ilişkilendirilmektedir (Daveri ve Tabellini, 2000:50). Vergi takozundaki değişimlerin istihdamı etkileme derecesini belirleyen temel unsurlardan birisi ise işgücü talebinin esnekliğidir (Trpeski ve Tashevska, 2012:572). Bu kapsamda, işgücü talebi ne kadar esnekse, istihdam için vergi takozu o kadar zararlı olacaktır (Todorović vd. 2018: 65). Mevcut kanitlar, işletmelerin üretim bileşimini kolay değiştirebildiğini, bu nedenle de başta düşük vasıflı işçiler için olmak üzere uzun vadede işgücü talebi esnekliğinin yüksek olduğunu ortaya koymaktadır (Attinasi vd. 2016: 5).

Çalışanların motivasyonunun önemli bir kısmı kazandıkları gelir ile gerçekleştirebilecekleri tüketimden gelmektedir. Bu nedenle vergi takozundaki değişimler, istihdamı, işgücü talebinin yanı sıra işgücü arzı üzerinden de etkilemektedir. Gelir vergileri ve çalışanların sosyal güvenlik primlerindeki artış veya azalışlar çalışmanın getirisini etkileyeceğinden, bireylerin işgücü piyasasına girip girmeme, boş zaman-çalışma süresi ya da ücretsiz istihdamı seçme (örneğin çocuk bakımı) gibi kararlarını da yakından etkileyecektir (Ederveen ve Thissen, 2004: 18; Behar 2009; 81). Bu açıdan vergi takozunun işgücü arz miktarı üzerinde gelir ve ikame olmak üzere iki farklı etkisi söz konusudur. Gelir etkisine göre yüksek vergi takozu harcanabilir geliri azalttığından boş zaman talebi azalacak ve 
işgücü arz miktarı artacaktır. İkame etkisine göre ise yüksek vergi takozu daha düşük bir çalışma getirisine yol açacağından çalışma teşviki ile birlikte işgücü arz miktarı azalacaktır. Dolayısıyla vergi takozunun işgücü arz miktarı üzerindeki teorik etkisinin belirsiz olduğu söylenebilir (Attinasi vd. 2016: 4). Ancak literatürde ikame etkisinin gelir etkisinden daha yüksek olduğu bu nedenle de vergi takozundaki yükselmenin işgücü arz miktarını azalttı̆̆ı vurgulanmaktadır. Buna göre vergi takozundaki yükselmeler bireylerin daha çok kayıt dışı sektör veya hane halkı faaliyetleri gibi resmi olmayan sektörlerde faaliyet göstermesine yol açmakta, bu ise gelir etkisinin kaynağını gerekçelendirmeyi zorlaştırmaktadır (Behar, 2009: 81-82; Ederveen ve Thissen, 2004: 11; Y1lanc1 vd., 2019: 288-289). Burada önemli olan bir diğer nokta ise işgücü arz esnekliğidir. Bu kapsamda, ikame etkisinin gelir etkisinden büyük olduğu varsayımı altında, arz eğrisinin esnekliği arttıkça vergi takozunun istihdam üzerindeki olumsuz etkisi de artacaktır (Góra vd. 2006:7). Diğer taraftan Attinasi vd. (2015)'e göre işgücü arzının vergi esnekliği erkeklerle karşılaştırıldığında kadınlarda daha yüksektir. Kadınların toplam geliri içerisinde sermaye gelirlerinin (faiz, temettü vb.) payının düşük, buna karşın emek gelirinin payının yüksek olması, ücret üzerinden alınan vergilerden kadınların daha fazla etkilenmesine yol açabilir (Gunnarsson ve Spangenberg, 2019: 143). Bununla birlikte, erkeklerin büyük bir bölümü ücretli tam zamanlı işlerde çalışmaktayken, kadınlar 'zaman kısıtlaması' (çalışma zamanının iş ile ev arasında bölünmesi, evdeki zamanın ev işleri ile yaşlı ya da çocuk bakımı arasında bölünmesi) ve 'hareket kısıtlaması' (evine ve ailesine daha yakın işler seçmek zorunda olması) gibi sebeplerden ötürü yarı zamanlı ve daha düşük ücretli işlerde daha fazla yer alabilmektedirler (İlalan, 2017: 11). Bu nedenle de vergi takozundaki bir artışın kayıtlı istihdam üzerindeki caydırıcı etkisi kadınlar için daha yüksek olabilmektedir (Atoyan ve Rahman, 2017:15).

Vergi takozundaki değişimlerin, erkek ve kadınların çalışıp-çalışmama veya ne kadar çalışacakları gibi kararlarını farklı düzeyde etkileyebileceğinden hareketle bu çalışmada, 2000-2019 dönemini kapsayan yıllık verileri kullanarak, 36 Ekonomik Kalkınma ve İş birliği Örgütü (The Organisation for Economic Cooperation and Development- OECD) üyesi ülkede vergi takozunun toplam, erkek ve kadın işsizlik oranları üzerindeki etkilerinin ayrı ayrı araştırılması amaçlanmıştır. Vergi takozunun toplam işsizlik üzerindeki etkileri literatürde birçok çalışmaya konu olmuşken, erkek ve kadın istihdamını nasıl etkilediği noktasında ise bulgular oldukça sınırlıdır. Bu nedenle de bu çalışmanın literatüre ampirik katkı yapacağı, politika yapıcıları için kritik bilgiler sunacağı ve literatürdeki önemli bir boşluğu dolduracağı, düşünülmektedir.

\section{Literatür Taraması}

Vergi takozunun işsizlik üzerindeki etkileri farklı örneklem ve yöntemler ile birçok çalışmada ampirik olarak test edilmiştir. Bu çalışmalardan öne çıkanlar aşağıdaki gibi gösterilebilir: 
Thomas (1998), İsveç'te sigorta prim maliyetinin ve toplam işgücü vergilerinin işsizliği nasıl etkilediğini incelemiştir. 1970-1996 dönemini kapsayan verilerin ve Genelleştirilmiş Momentler yönteminin kullanıldığ maliyeti ve toplam vergilerdeki artışların işsizliği arttırdığı tespit edilmiştir. Nickell ve Layard (1999), OECD üyesi 20 ülkede 1983-1994 dönemi için vergi takozunun işsizlik üzerindeki etkisini araştırmıştır. Geleneksel En Küçük Kareler yöntemi ile vergi takozundaki ve sendikalaşma oranındaki artışların işsizliği arttırdığ 1 , enflasyondaki artışların ise işsizliği azalttığ Tabellini (2000), 14 sanayileşmiş OECD ülkesinde 1965-1991 döneminde ücretler üzerinden alınan vergilerin işsizlik ve ekonomik büyüme üzerindeki etkilerini araştırmıştır. Farklı tahmincilerin kullanıldığ ç̧alışmada vergilerdeki artışın hem istihdamı hem de büyümeyi azalttı̆̆ 1 belirlenmiştir. Ederveen ve Thissen (2004), 21 Avrupa ülkesinde 1960-99 döneminde işgücü piyasası kurumlarının işsizliği açıklayıp açıklamadığını araştırmıştır. Dengesiz panel veri setinin kullanıldığı çalışmada, işsizlik ödeneğinin süresindeki ve vergi takozundaki artışların işsizliği arttırdığı, daha sık1 istihdam koruması, daha fazla koordinasyonun ve enflasyondaki değişimlerin ise işsizliği azalttığı bulguları elde edilmiştir. Bassanini ve Duval (2006), 21 OECD ülkesi örnekleminde 1983-2003 yılları arasında ücret vergilendirmeleri ile diğer politikalar arasındaki olası etkileşimlerin istihdam ve işsizlik üzerinde etkilerini araştırmıştır. Ampirik analizler sonucunda yüksek ve uzun süreli işsizlik ödemelerinin ve yüksek vergi takozunun işsizliği arttırıp istihdam beklentilerini azalttığı belirlenmiştir. Góra vd. (2006), seçilmiş 27 OECD ve $A B$ üyesi ülkede vergi takozunun vasıflı ve vasıfsız işgücü üzerindeki etkisini 1997 ve 2003 yılları için yatay kesit analizi ile ele almıştır. Ampirik analiz sonucunda vergi takozunun vasıfsız işgücü istihdamını güçlü bir biçimde azalttığı, vasıflı işgücü üzerindeki etkisinin ise istatiksel olarak anlamlı olmadığı sonucuna ulaşılmıştır. Behar (2009), parametrik olmayan yöntemlerle 10 Orta ve Doğu Avrupa ülkesinde vergi takozunun işsizlik üzerindeki etkilerini araştırmıştır. Çalışmada yüksek vergi takozunun ve uygun olmayan sosyal yardım sistemlerinin işgücü piyasası üzerinde bozucu etkilerinin olduğu ortaya konulmuştur. Šeparović (2009), Hırvatistan için vergi takozu ile işsizlik arasındaki ilişkiyi irdelemiş ve vergi takozundaki artışların işsizlik üzerinde arttırıcı bir etkisinin olduğunu belirlemiştir. Dolenc ve Laporšek (2010), 1999-2008 dönemini kapsayan verileri kullanarak panel regresyon analizi ile Avrupa birliğine üye 27 ülkede vergi takozu ile işsizlik arasındaki ilişkiyi incelemişlerdir. Çalışmada vergi takozundaki artışların istihdamı azalttığı bulgusu elde edilmiştir.

Trpeski ve Tashevska (2012), OECD, AB ve AB üye ülke sınıfında yer alan 43 ülkede vergi takozu ve işsizlik arasındaki ilişkiyi ele almıştır. Kümeleme analizinin gerçekleştirildiği çalışmada yüksek vergi takozunun olduğu ülkelerde işsizliğin yüksek, düşük vergi takozunun olduğu ülkelerde ise işsizliğin düşük olduğu bulgusu elde edilmiştir. Attinasi vd. (2016), 1979-2014 dönemini kapsayan verileri kullanarak 30 OECD üyesi ülkede vergi takozunun işgücü piyasası üzerindeki etkilerini araştırmışlardır. Havuzlanmış En Küçük Kareler, 
Sabit Etkiler ve Araç Değişken tahmincilerinin kullanıldığı çalışmada, vergi takozu ile istihdam seviyesi arasında olumsuz bir ilişkinin varlığı tespit edilmiştir. Ayrıca vergi takozundaki artışların bekâr gelirliler ve vasıfsız işgücünü daha fazla etkilediği belirtilmiştir. Atoyan ve Rahman (2017), 37 Avrupa ülkesinde, 20062016 yılları arasında vergi takozunun toplam, kadın ve erkek istihdamı üzerindeki etkilerini araştırmıştır. Panel regresyon analizinin kullanıldığı çalışmada vergi takozunun her üç istihdam türü üzerindeki etkisi de istatiksel olarak anlamsız bulunmuştur. Kutbay vd. (2018), 1989SY01-2016SY02 dönemini kapsayan verileri kullanarak Türkiye'de asgari ücretin ve vergi takozunun işsizlik üzerindeki etkilerini Dinamik En Küçük Kareler yöntemi ile irdelemiştir. Ampirik analizlerin sonucunda hem asgari ücretteki hem de vergi takozundaki artışların işsizliği arttırdığı tespit edilmiştir. Yılancı vd. (2019), OECD üyesi yedi gelişmekte olan ülke için 2000-2017 dönemini kapsayan verileri kullanarak işsizlik ile vergi takozu arasındaki nedensellik ilişkisini incelemiştir. Konya nedensellik testinin sonucuna göre; sadece Macaristan, Meksika ve Polonya'da vergi takozundan işsizliğe doğru tek yönlü bir nedensellik vardır.

Literatür incelendiğinde; çalışmaların çok önemli bir kısmının vergi takozundaki artışların işsizliği arttırdığı yönünde bulgu elde ettikleri görülmektedir. Bununla birlikte, bu çalışmaların genellikle vergi takozunun toplam işsizlik üzerindeki etkilerini araştırdığı, kadın ve erkek işsizliği üzerindeki etkilerini ayrı ayrı inceleyen ise sadece bir çalışmanın olduğu belirtilmelidir. Oysa vergi takozunun kadın ve erkek istihdamı üzerindeki etkilerinin ayrı ayrı incelenmesi, politika yapıcılar için önemli bilgiler sağlayabilir ve işsizliği azaltmaya yönelik oluşturulacak politikaların etkinliğini ve çeşitliliğini arttırabilir. Literatürdeki bu boşluğu doldurmak amacıyla bu çalışmada, vergi takozunun toplam, erkek ve kadın işsizlik oranları üzerindeki etkileri ayrı ayrı incelenmiştir.

\section{Model ve Veri Seti}

$\mathrm{Bu}$ çalışmada vergi takozunun 36 OECD üyesi ülkede toplam, kadın ve erkek işsizliğini nasıl etkilediği, aşağıda yer alan üç farklı dinamik model yardımıyla incelenmiştir. Dinamik model tercih edilmesinin temel nedeni; literatürde yavaş değiştiği ve bundan dolayı geçmiş değerlerinin önemli bir açıklama gücüne sahip olduğu kabul edilen işsizliği daha iyi açıklayabilmektir.

$$
\begin{aligned}
& \text { Unempt }_{i, t}=\beta_{0}+\beta_{1} \text { Unempt }_{i, t-1}+\beta_{2} \text { Taxwedge }_{i, t}+\beta_{3} \text { Growth }_{i, t}+\beta_{4} \text { Inf }_{i, t}+\beta_{5} \text { Trdop }_{i, t}+\varepsilon_{i, t} \\
& \text { Unempf }_{i, t}=\beta_{0}+\beta_{1} \text { Unempf }_{i, t-1}+\beta_{2} \text { Taxwedge }_{i, t}+\beta_{3} \text { Growth }_{i, t}+\beta_{4} \text { Inf }_{i, t}+\beta_{5} \text { Trdop }_{i, t}+\varepsilon_{i, t} \\
& \text { Unempm }_{i, t}=\beta_{0}+\beta_{1} \text { Unempm }_{i, t-1}+\beta_{2} \text { Taxwedge }_{i, t}+\beta_{3} \text { Growth }_{i, t}+\beta_{4} \text { Inf }_{i, t}+\beta_{5} \text { Trdop }_{i, t}+\varepsilon_{i, t}
\end{aligned}
$$

Burada, " $t$ ”, zaman aralığını (2000-2019), “ $i ”, \quad$ birim sayısını (36), " $\beta_{1}, \beta_{2}, \beta_{3}, \beta_{4}, \beta_{5}$ ", parametre katsayılarını, " $\beta_{0}$ ", sabiti ve " $\varepsilon$ " hata terimini temsil etmektedir. Bağımlı değişkenler "Unempt", "Unempf" ve "Unempm" sırasıyla toplam, kadın ve erkek işsizlik oranlarını temsil etmektedir ve 
gecikmeleri modellere bağımsız değişken olarak eklenmiştir. Modeldeki temel bağımsız değişken olan "Taxwedge" vergi takozunu, ihmal edilmiş değişken sapmasına yol açmamak için modele kontrol değişkenleri olarak eklenmiş "Growth", "Inf" ve "Trdop" ise sirasıyla yıllık reel büyüme oranını, GSYH deflatörü üzerinden hesaplanmış enflasyon oranını ve ticari açıklık oranını temsil etmektedir. Vergi takozuna ait veriler OECD (2020b) veri tabanından, geri kalan veriler ise Dünya Bankası (2020) veri tabanından elde edilmiştir.

\section{Ampirik Yöntem ve Bulgular}

Doğru ekonometrik araçlar seçebilmek ve etkin tahminler elde edebilmek için öncelikle değişkenlerin durağanlık özellikleri incelenmelidir. Bu nedenle ampirik analizin ilk aşamasında modelde yer alan değişkenlerin durağanlık özellikleri Maddala and $\mathrm{Wu}$ (1999) ve (Choi, 2001) tarafindan geliştirilen Fisher ADF ve Fisher PP, Levin, Lin, and Chu (2002) tarafindan geliştirilen LLC ve Im, Pesaran, and Shin (2003) tarafından geliştirilen IPS birim kök testleriyle incelenmiş ve sonuçlar aşağıda Tablo 1'de gösterilmiştir.

Tablo 1: Birim Kök Test Sonuçları

\begin{tabular}{|c|c|c|c|c|c|}
\hline Değişkenler & Model & $\mathbf{L L C}$ & IPS & $\begin{array}{l}\text { ADF-Fisher } \\
\text { Chi-square }\end{array}$ & $\begin{array}{l}\text { PP - Fisher } \\
\text { Chi-square }\end{array}$ \\
\hline \multirow[t]{3}{*}{ Unempt } & $\mathrm{C}$ & $-2.63(0.004)$ & $-3.11(0.000)$ & $109.34(0.003)$ & $60.93(0.820)$ \\
\hline & $\mathrm{C}+\mathrm{T}$ & $-2.00(0.022)$ & $-1.59(0.055)$ & $91.63(0.049)$ & $36.71(0.999)$ \\
\hline & Non & $-3.74(0.000)$ & & $74.03(0.411)$ & $76.07(0.348)$ \\
\hline \multirow[t]{3}{*}{ Unempf } & $\mathrm{C}$ & $-2.32(0.009)$ & $-2.42(0.007)$ & $105.32(0.006)$ & $62.00(0.793)$ \\
\hline & $\mathrm{C}+\mathrm{T}$ & $-2.44(0.007)$ & $-2.02(0.021)$ & $95.65(0.032)$ & $37.14(0.999)$ \\
\hline & Non & $-4.23(0.000)$ & & $83.00(0.176)$ & $83.60(0.164)$ \\
\hline \multirow[t]{3}{*}{ Unempm } & $\mathrm{C}$ & $-3.15(0.000)$ & $-3.42(0.000)$ & $112.17(0.001)$ & $67.48(0.628)$ \\
\hline & $\mathrm{C}+\mathrm{T}$ & $-3.17(0.000)$ & $-2.63(0.004)$ & $109.64(0.002)$ & $43.99(0.996)$ \\
\hline & Non & $-3.48(0.000)$ & & $78.57(0.276)$ & 74.07(0.410) \\
\hline \multirow[t]{3}{*}{ Taxwedge } & $\mathrm{C}$ & $-1.77(0.037)$ & $0.19(0.577)$ & $69.37(0.498)$ & $77.48(0.308)$ \\
\hline & $\mathrm{C}+\mathrm{T}$ & $-1.89(0.029)$ & $-1.23(0.108)$ & $84.39(0.115)$ & $62.86(0.770)$ \\
\hline & Non & $-2.65(0.003)$ & & $84.97(0.107)$ & $99.85(0.173)$ \\
\hline \multirow[t]{3}{*}{ Growth } & $\mathrm{C}$ & $-14.17(0.000)$ & $-12.04(0.000)$ & $274.16(0.000)$ & $306.54(0.000)$ \\
\hline & $\mathrm{C}+\mathrm{T}$ & $-11.72(0.000)$ & $-8.53(0.000)$ & $194.14(0.000)$ & $245.50(0.000)$ \\
\hline & Non & $-10.32(0.000)$ & & $254.30(0.000)$ & $269.36(0.000)$ \\
\hline \multirow[t]{3}{*}{ Inf } & $\mathrm{C}$ & $-9.65(0.000)$ & $-9.87(0.000)$ & $235.10(0.000)$ & $229.35(0.000)$ \\
\hline & $\mathrm{C}+\mathrm{T}$ & $-8.92(0.000)$ & $-8.69(0.000)$ & $204.06(0.000)$ & $180.32(0.000)$ \\
\hline & Non & $-6.64(0.000)$ & & $141.39(0.000)$ & $174.93(0.000)$ \\
\hline \multirow[t]{3}{*}{ Trdop } & $\mathrm{C}$ & $-2.28(0.011)$ & $1.16(0.877)$ & $54.54(0.937)$ & $56.21(0.914)$ \\
\hline & $\mathrm{C}+\mathrm{T}$ & $-5.01(0.000)$ & $-3.49(0.000)$ & $111.86(0.001)$ & $96.62(0.028)$ \\
\hline & Non & $3.46(0.999)$ & & $22.17(1.00)$ & $19.77(1.000)$ \\
\hline \multicolumn{6}{|c|}{$\begin{array}{l}\text { Not: Birim kök testlerinde kullanılan modeller: "C+T" trend ve sabiti içerir, "C"sadece sabiti } \\
\text { içerir, "Non" sabit ve trend içermez şeklindedir. Maksimum gecikme uzunluğu } 2 \text { olarak olarak } \\
\text { alınmış olup, optimal gecikme uzunluğunun belirlenmesinde Akaike bilgi kriterlerinden } \\
\text { faydalanılmıştır. Olasılık değerleri parantez içinde gösterilmektedir. }\end{array}$} \\
\hline
\end{tabular}


Tablo 1 incelendiğinde; birim kök testlerinin değişkenlerin durağanlık özelliklerine yönelik farklı sonuçlar ortaya koyduğu görülmektedir. Penel birim kök testlerinin bu özelliği ile literatürde sıklıkla karşılaşılmakta ve böyle durumlarda genellikle test istatistiklerinin çoğunluğunun hangi yönü gösterdiği dikkate alınmaktadır (Baltagi ve Pirotte, 2010: 277-286). Buradan hareketle, iktisadi büyüme oranın, enflasyon oranın ve toplam, kadın ve erkek işsizlik oranlarının durağan olduğu, ticari açıklık ve vergi takozunun durağan olmadığını kabul etmekteyiz.

Dinamik modellerde, bağımlı değişkenin gecikmeli değerinin bağımsız değişken olarak modelde yer alıyor olması içsellik problemine yol açtığından, bu modellerin tahmininde bilindik tahminciler kullanılamamaktadır (Bond, 2002; Baum, 2006; Akalin ve Uzgören, 2019). Dinamik modelin tahmini için genellikle literatürde Anderson ve Hsiao (1981) tarafindan geliştirilen Araç Değişken (Instrumental Variables) tahmincisi, Arellano ve Bond (1991) tarafindan geliştirilen Genelleştirilmiş Momentler Yöntemi (Generalized Method of Moments) tahmincisi ve Arellano ve Bover (1995) ve Blundell ve Bond (1998) tarafindan geliştirilen Sistem GMM (System Generalized Method of Moments) tahmincisi kullanılmaktadır. Fakat Araç Değişken tahmincisi ve Genelleştirilmiş Momentler Yöntemi ya da diğer adıyla Fark GMM tahmincisi, değişkenlerin rassal yürüyüşe tabi olması durumunda zayıf araç değişken kullanımına yol açmaktadır (Han ve Phillips, 2010: 119-120; Lee ve Azali, 2010: 167; Tatoğlu, 2013: 85-86). Arellano ve Bover (1995) ve Blundell ve Bond (1998) bu sorunun üstesinden gelinebilmesi için "birinci fark" dönüşümü yerine "ortogonal sapmalar" yönteminin kullanılmasını önermektedir. Bu yöntem, fark denklemi ile düzey denklemlerinin birleştirilmesine dayanmakta ve birinci farklar yönteminin aksine cari dönemden bir önceki dönemin farklı alınmamakta, bunun yerine bir değişkenin tüm mümkün gelecek değerlerinin ortalamasının farkı alınmaktadır (Tatoğlu, 2013: 86). Böylece değişkenlerin rassal yürüyüşe tabi olması durumunda bile Sistem GMM ile daha etkin tahminler elde edilebilmektedir (Bond, 2002; Roodman, 2009). Diğger taraftan, yapmış oldukları Monte Carlo simülasyonları ile Blundell, Bond, ve Windmeijer (2001) sonlu örneklemlerde, Soto (2009) ise küçük örneklemlerde Sistem GMM tahmincisinin Fark GMM tahmincisine göre daha sapmasız ve daha etkin olduğunu kanıtlamışlardır. $\mathrm{Bu}$ nedenlerden ötürü dinamik modelin tahmini için bu çalışmada Sistem GMM tahmincisi tercih edilmiştir. Sistem GMM tahmincisi ile elde edilen bulgular ve tahminlerin güvenirliliğini kontrol etmek için gerçekleştirilen bazı tanı testlerinin sonuçları aşağıda Tablo 2'de gösterilmiştir. 
Tablo 2: Sistem GMM Tahmin Sonuçları

\begin{tabular}{|c|c|c|c|}
\hline Değişkenler & Model 1 & Model 2 & Model 3 \\
\hline Unempt $t-1$ & $\begin{array}{l}0.917 * * * \\
(0.000)\end{array}$ & & \\
\hline Unempf $_{\mathrm{t}-1}$ & & $\begin{array}{l}0.934 * * * \\
(0.000)\end{array}$ & \\
\hline Unempm $_{t-1}$ & & & $\begin{array}{l}0.892 * * * \\
(0.000)\end{array}$ \\
\hline Taxwedge & $\begin{array}{l}0.055 * * * \\
(0.003)\end{array}$ & $\begin{array}{l}0.046^{* *} \\
(0.015) \\
\end{array}$ & $\begin{array}{l}0.049 * * * \\
(0.001)\end{array}$ \\
\hline Growrth & $\begin{array}{l}-0.336 * * * \\
(0.000)\end{array}$ & $\begin{array}{l}-0.273 * * * \\
(0.000)\end{array}$ & $\begin{array}{l}-0.392 * * * \\
(0.000)\end{array}$ \\
\hline Inf & $\begin{array}{l}-0.038^{* * *} \\
(0.000)\end{array}$ & $\begin{array}{l}-0.042 * * * \\
(0.000)\end{array}$ & $\begin{array}{l}-0.033 * * * \\
(0.000)\end{array}$ \\
\hline Trdop & $\begin{array}{l}-0.021 * * * \\
(0.000)\end{array}$ & $\begin{array}{l}-0.021 * * * \\
(0.000)\end{array}$ & $\begin{array}{l}-0.021 * * * \\
(0.000)\end{array}$ \\
\hline \multicolumn{4}{|l|}{ Tanı Testleri } \\
\hline Sargan & $\begin{array}{l}30.48 \\
(0.492) \\
\end{array}$ & $\begin{array}{l}31.16 \\
(0.458) \\
\end{array}$ & $\begin{array}{l}34.10 \\
(0.320) \\
\end{array}$ \\
\hline AR (2) & $\begin{array}{l}-0.355 \\
(0.721) \\
\end{array}$ & $\begin{array}{l}0.971 \\
(0.331) \\
\end{array}$ & $\begin{array}{l}-0.758 \\
(0.448) \\
\end{array}$ \\
\hline
\end{tabular}

Tahminlerin güvenirliliğine yönelik gerçekleştirilen tanı testlerinin sonuçları incelendiğinde, Sargan testinin sonucuna göre "araç değişkenler geçerlidir" şeklindeki $\mathrm{H}_{0}$ hipotezi, ve Arellano-Bond otokorelasyon testinin (AR 2) sonucuna göre "ikinci dereceden otokorelasyon yoktur" şeklindeki $\mathrm{H}_{0}$ hipotezi her üç model için de kabul edilmektedir. $\mathrm{Bu}$ sonuçlar modellerde ikinci dereceden otokorelasyon olmadığını, araç değişkenlerin geçerli olduğunu dolayısıyla tahminlerin güvenilir olduğunu ortaya koymaktadır.

Elde edilen katsayılar incelendiğinde; tüm katsayıların istatiksel olarak anlamlı olduğu, vergi takozundaki artışların toplam, kadın ve erkek işsizlik oranlarını arttırdığı, iktisadi büyüme oranında, enflasyon oranında ve ticari açıklıkta ortaya çıkan artışların ise toplam, kadın ve erkek ișsizlik oranlarını azalttığı görülmektedir. Ayrıca geçmiş işsizlik düzeyinin mevcut işsizlik düzeyini açıklamada çok önemli bir faktör olduğu da tespit edilmiștir. Elde edilen bulguların Thomas (1998), Nickell ve Layard (1999), Daveri ve Tabellini (2000), Ederveen ve Thissen (2004), Bassanini ve Duval (2006), Behar (2009), Šeparović (2009), Dolenc ve Laporšek (2010), Trpeski ve Tashevska (2012), Attinasi vd. (2016) ve Kutbay vd. (2018) ile uyumlu olduğu, Góra vd. (2006) ve Atoyan ve Rahman (2017) ile ise kısmen uyumsuz olduğu söylenebilir.

İktisadi büyümenin istihdamı arttırıcı etkisi yaygın olarak bilinmekte ve literatürde bir fikir birliği bulunmaktadır. İktisadi büyümeden kasıt üretilen mal ve hizmet miktarındaki artış olduğundan, büyüme ile birlikte üretimde kullanılan 
üretim faktörlerinin talebi de artabilir. Ticari açıklıktaki artışın işsizlik üzerindeki azaltıcı etkisi de bu kapsamda ele alınabilir ve ticari açıklığın ekonomik büyüme üzerindeki arttırıcı etkisi ile açıklanabilir.

Vergi takozunun istihdam üzerindeki bozucusu etkisi, vergi takozundaki artışların maliyetleri yükselterek işgücü talebini azaltması ve çalışanların daha düşük gelir elde etmesine yol açarak işgücü arzını azaltması ile açıklanabilir. Diğer taraftan, beklentilerimizin aksine vergi takozundaki artışlar kadınlara kıyasla, erkek işsizlik oranlarını daha fazla arttırmaktadır. $\mathrm{Bu}$ ise vergi takozundaki artışların erkek ve kadınların işgücüne katılım oranlarını farklı etkilemesinden kaynaklanıyor olabilir.

İktisat literatüründe, enflasyon ile işsizlik arasındaki ilişki, Philips (1958) eğrisi hipotezi çerçevesinde sıklıkla ele alınan konulardan birisidir. Philips orijinal çalışmasında nominal ücretler ile işsizlik arasındaki ilişkiyi araştırmış ve iki değişken arasında ters yönlü bir ilişki olduğunu tespit etmiştir. Daha sonraki çalışmalarda ise bu ilişki nominal ücretlerden ziyade, enflasyon ile işsizlik arasında ters yönlü bir ilişki biçiminde ele alınmıştır. Enflasyon ile işsizlik arasındaki ters yönlü bu ilişkiye yönelik en önemli teorik açıklama ise daha öncesinde Irwing Fisher (1926) tarafından yapılmıştır. Fisher'a göre üretim maliyetlerinin fiyat değişimlerine geç tepki vermesi ve bu nedenle enflasyonun işverenlerin harcamalarına kıyasla kazançlarını daha fazla arttırması, işverenlerin istihdamı arttırıcı yönde hareket etmesine yol açmaktadır (Altay vd. 2011; Bayrak ve Kanca, 2013). Bu açıdan enflasyondaki artışların işsizlik üzerindeki azaltıcı etkisin de teorik beklentilere uygun olduğu söylenebilir.

\section{Sonuç ve Politika Önerileri}

İşsizlik çağımızın en temel iktisadi problemlerinden birisidir. Bu nedenle de hem politika yapıcıların hem de araştırmacıların sürekli ilgisini çekmektedir. Literatürdeki teorik ve ampirik çalışmalar işsizliğin önemli belirleyicilerinden bir tanesinin de vergi takozu olduğunu ortaya koymaktadır. Buradan hareketle bu çalışmada vergi takozunun işsizlik üzerindeki etkileri 36 OECD ülkesi için Sistem GMM yöntemiyle araştırılmıştır. Literatürden farklı olarak bu çalışmada vergi takozunun işsizlik üzerindeki etkileri toplam, kadın ve erkekler için ayrı ayrı araştırılmıştır. Elde edilen ampirik bulgular ve bu bulgulara dayalı politika önerileri şöyle sıralanabilir: iktisadi büyüme ve ticari açıklığın işsizlik üzerinde azaltıcı bir etkisi vardır. $\mathrm{Bu}$ nedenle hükümetler, sürdürülebilir bir iktisadi büyümeyi sağlamak amacıyla geniş ölçekli makroekonomik politikalar ve diş ticareti kısıtlayıcı engelleri kaldırmaya ve dış ticareti desteklemeye yönelik politikalar tasarlamalıdır.

Enflasyondaki bir artış işsizliği azaltmaktadır. Bu bulgu, enflasyonun işsizliği kontrol etmeye yönelik kullanılabilecek önemli bir araç olduğunu göstermektedir. Bununla birlikte enflasyonun kaynak tahsisi, gelir dağılımı ve tasarruflar üzerindeki bozucu etkileri de gözden kaçırılmamalıdır. Vergi takozundaki 
artışların işsizliği arttırdığı tespit edilmiştir. Bu bulgu, politika yapıcılarının vergi indirimlerine giderek işsizliği azaltabileceğini göstermektedir. Ancak mali açıdan sorunlu ülkelerde istihdamı arttırmak için yapılacak vergi indirimleri bütçe açıklarını daha da arttırabilir. Bu nedenle, vergileri indirmek ile katlanılacak mali risk arasındaki denge iyi kurgulanmalıdır. Son olarak, vergi takozunun erkek ve kadın işsizlik oranları üzerindeki etkisini inceleyecek daha sonraki çalışmaların, işgücüne katılım oranlarını dikkate almaları önerilmektedir.

\section{Kaynakça}

Akalin, G. ve Uzgören, E. (2019). Kurumsal Kalitenin Gelir Dağılımı Üzerindeki Etkisi: Gelişmiş Ve Gelişmekte Olan Ülkeler İçin Ampirik Bir Analiz. Eskişehir Osmangazi Üniversitesi İktisadi ve İdari Bilimler Dergisi, 14(1), 201-224.

Altay, B., Tuğcu, C. T. ve Topçu, M. (2011). İşsizlik Ve Enflasyon Oranları Arasındaki Nedensellik İlişkisi: G8 Ülkeleri Örneği. Afyon Kocatepe Üniversitesi Iktisadi ve İdari Bilimler Fakültesi Dergisi, 13(2), 1-26.

Anderson, T. W. ve Hsiao, C. (1981). Estimation of Dynamic Models with Error Components. Journal of the American statistical Association, 76(375), 598606.

Arellano, M. ve Bond, S. (1991). Some Tests of Specification for Panel Data: Monte Carlo Evidence and an Application to Employment Equations. The Review Of Economic Studies, 58(2), 277-297.

Arellano, M. ve Bover, O. (1995). Another Look at the Instrumental Variable Estimation of Error-Components Models. Journal of Econometrics, 68(1), 2951 .

Atoyan, M. R. V., \& Rahman, J. (2017). Western Balkans: Increasing Women's Role in the Economy. International Monetary Fund.

Attinasi, M. G., Berardini, F., De Stefani, R., \& Osterloh, S. (2016). The Effects of Labor Income Taxes on Labor Market Performance: An Empirical Analysis. Working Paper.

Baltagi, B. H. ve Pirotte, A. (2010). Panel Data Inference under Spatial Dependence. Economic Modelling, 27(6), 1368-1381.

Bassanini, A. ve Duval, R. (2006). Employment Patterns in OECD Countries: Reassessing the Role of Policies and Institutions. OECD Economics Department Working Papers, No. 486. OECD Publishing (NJ1).

Baum, C. F. (2006). An Introduction to Modern Econometrics Using Stata: Stata press. 
Bayrak, M., ve Kanca, O. C. (2013). Türkiye'de Phillips Eğrisi Üzerine Bir Uygulama. Eskişehir Osmangazi Üniversitesi İktisadi ve İdari Bilimler Dergisi, 8(3), 97-116.

Behar, A. (2009). Tax Wedges, Unemployment Benefits and Labour Market Outcomes in the New EU Members. Czech Economic Review, 3(01), 69-92.

Blundell, R. ve Bond, S. (1998). Initial Conditions and Moment Restrictions in Dynamic Panel Data Models. Journal of Econometrics, 87(1), 115-143.

Blundell, R., Bond, S. ve Windmeijer, F. (2001). Estimation in Dynamic Panel Data Models: Improving on the Performance of the Standard GMM Estimator. Emerald Group Publishing Limited.

Bond, S. (2002). Dynamic Panel Models: A Guide to Micro Data Methods and Practice (Working Paper No. CWPO9/02). London, UK: Institute for Fiscal Studies.

Choi, I. (2001). Unit Root Tests for Panel Data. Journal of International Money and Finance, 20(2), 249-272.

Daveri, F. Ve Tabellini, G. (2000). Unemployment, Growth and Taxation in Industrial Countries. Economic Policy, 15(30), 48-104.

Dolenc, P. ve Laporšek, S. (2010). Tax Wedge on Labor and Its Effect on Employment Growth in the European Union. Prague Economic Papers, 4(2010), 344-358.

Dünya Bankası (2020), Dünya Gelişme Göstergeleri (Word Development Indicators) Veri Taban1. http://data.worldbank.org/data-catalog/worlddevelopment-indicators. (Erişim: 15.05.2020.

Ederveen, S. ve Thissen, L. (2004). Can Labour Market Institutions Explain Unemployment Rates in New EU Member States?. European Network of Economic Policy Research Institutes (No. 27, p. 47). Working Paper.

Góra, M., Radziwill, A., Sowa, A. ve Walewski, M. (2006). Tax Wedge and Skills: Case of Poland in International Perspective. CASE Network Reports, (64).

Gunnarsson, A. ve Spangenberg, U. (2019). Gender Equality and Taxation Policies in the EU. Intereconomics, 54(3), 141-146.

Han, C. ve Phillips, P. C. (2010). GMM Estimation for Dynamic Panels with Fixed Effects and Strong Instruments at Unity. Econometric theory, 119-151.

Hodge, S. A. ve Hickman, B. (2018). The Importance of the Tax Wedge on Labor in Evaluating Tax Systems. https://files.taxfoundation.org/20180913095728/GlobalPrimer_tax_wedge.pdf. (Erişim: 04.01.2020). 
Im, K. S., Pesaran, M. H. ve Shin, Y. (2003). Testing for Unit Roots in Heterogeneous Panels. Journal of Econometrics, 115(1), 53-74.

İlalan, İ. (2017). OECD Ülkelerinde Kadın İşgücüne Katılımın Ekonomik Kalkınma Ve Vergi Yükü Açısından Analizi. Yayınlanmamış Doktora Tezi, Hacettepe Üniversitesi Sosyal Bilimler Enstitüsü, Ankara.

Kutbay, H., Gerede, C. ve Aksoy, E. (2018). Asgari Ücret Üzerindeki Vergi Takozunun İssizliğe Etkisi. Vergi Raporu, Mayıs, 224, 96-114.

Lee, G. H. ve Azali, M. (2010). The Endogeneity of the Optimum Currency Area Criteria in East Asia. Economic Modelling, 27(1), 165-170.

Levin, A., Lin, C.-F. ve Chu, C.-S. J. (2002). Unit Root Tests in Panel Data: Asymptotic and Finite-Sample Properties. Journal of Econometrics, 108(1), 124.

Maddala, G. S. ve Wu, S. (1999). A Comparative Study of Unit Root Tests with Panel Data and A New Simple Test. Oxford Bulletin of Economics and Statistics, 61(S1), 631-652.

Nickell, S. ve Layard, R. (1999). Labor Market Institutions and Economic Performance. Handbook of Labor economics, 3, 3029-3084.

OECD (2006), Society at a Glance: OECD Social Indicators. https://www.oecdilibrary.org/social-issues-migration-health/society-at-a-glance2006_soc_glance-2006-en. (Erişim: 04.09.2020).

OECD (2020a), Taxing Wages 2020, OECD Publishing, Paris, https://doi.org/10.1787/047072cd-en.4.

OECD (2020b), OECD veri taban1, https://data.oecd.org/tax/tax-wedge.htm. (Erişim: 10.05.2020).

Roodman, D. (2009). How to do Xtabond2: An Introduction to Difference and System GMM in Stata. The Stata journal, 9(1), 86-136.

Šeparović, A. (2009). The Influence of the Tax Wedge on Unemployment in OECD Countries in Comparison with Croatia. Financial Theory and Practice, 33(4), 449-463.

Soto, M. (2009). System GMM Estimation with a Small Sample. UFAE and IAE Working Papers, 780.09.

Tatoğlu, F. Y. (2013). Illeri Panel Veri Analizi-Stata Uygulamall, İstanbul: Beta Basım Yayın Dağıtım AŞ.

Trpeski, P. ve Tashevska, B. (2012). Labour Tax Wedge in the Republic of Macedonia-Trends and International Comparison. Annales Universitatis Apulensis Series Oeconomica. 
Thomas, A. (1998). The Effects of Tax Wedges on Hours Worked and Unemployment in Sweden, IMF Working Paper, October, WP/98/152.

Todorović, J. Đ., Đorđević, M. ve Ristić, M. (2018). The Tax Wedge as the Determinant of Unemployment: A Comparatıve Overview of OECD Countries and Serbia. 49th International Scientific Conference Quantitative and Qualitative Analysis in Economics.

Yılancı, V., Yavuz, H. ve İnce, T. (2019). Seçilmiş OECD Ülkelerinde Vergi Takozu-İşsizlik İlişkisi. Maliye Dergisi, Ocak-Haziran; 176:286-297. 